\title{
Penerapan Algoritma Profile Matching pada Aplikasi Computer Based Test (CBT) dalam Proses Seleksi Mahasiswa Baru
}

\author{
Lusy Robiatul Fadilah ${ }^{1}$, Rianto $^{2}$, Rahmi Nur Shofa ${ }^{3}$ \\ 1,2,3 Informatika, Universitas Siliwangi, Jl. Siliwangi No. 24 Kahuripan Kecamatan Tawang, \\ Kota Tasikmalaya, Jawa Barat, 46115 \\ e-mail: ${ }^{1} 167006039 @$ student.unsil.ac.id, ${ }^{2}$ rianto@unsil.ac.id, ${ }^{3}$ rahmi@unsil.ac.id
}

Submitted Date: December $03^{\text {rd }}, 2020$

Revised Date: January $08^{\text {th }}, 2021$
Reviewed Date: December $31^{\text {st }}, 2020$

Accepted Date: June 14 $4^{\text {th }}, 2021$

\begin{abstract}
Computer Based Test (CBT) is a test that is administered using a computer as tools or the main medium in conducting tests or exams. However, not all universities have utilized this technology. One of them is the Sekolah Tinggi Ilmu Kesehatan (STIKes) Kuningan, which has not yet used a computerized system. Examination implementation and manual processing of exam scores are an obstacle in the selection process for new students. With the existence of a Computer Based Test (CBT) application, it is hoped that it can facilitate the implementation of the test. However, the use of Computer Based Test (CBT) technology is not sufficient in determining which participants get the best score. The Profile Matching algorithm is chosen as an algorithm that can assist in decision making. There are 5 criteria used, that is the value of CBT and parents' income as criteria for the type of Core Factor, Mathematics National Exam scores, English National Exam scores, and Indonesian Language National Exam scores as criteria for the type of Secondary Factor. Testing is done by comparing the results of calculations on the system and Microsoft Excel calculations where there are 3 different values of the Core Factor and Secondary Factor. There is a discrepancy in the test results when multiple profiles have the same final value. One of them, Dea Nur Alifah and Rahma Nurlita with CF values of 60\%, SF 40\% and CF 70\%, SF 30\% has a final value of 5.78, is in the order of 3 and 4 . Furthermore, the CF values of $80 \%$ and SF $20 \%$ are both has decreased in value, to 5.77 and still ranks 3 and 4. The application of the Profile Matching algorithm with an output in the form of ranking values in the Computer Based Test (CBT) application is still not optimal.
\end{abstract}

Keywords: Computer Based Test (CBT); Decision Support System; Profile Matching; Scoring Algorithm

\section{Abstrak}

Computer Based Test (CBT) adalah tes yang diselenggarakan menggunakan komputer sebagai alat atau media utamanya dalam pelaksanaan tes atau ujian. Namun, belum semua perguruan tinggi memanfaatkan teknologi tersebut. Salah satunya Sekolah Tinggi Ilmu Kesehatan (STIKes) Kuningan, yang belum menggunakan sistem terkomputerisasi. Pelaksanaan ujian serta pengolahan nilai ujian yang dilakukan secara manual, menjadi kendala dalam proses seleksi mahasiswa baru. Dengan adanya sebuah aplikasi Computer Based Test (CBT), diharapkan dapat mempermudah dalam pelaksanaan ujian tersebut. Namun, pemanfaatan teknologi Computer Based Test (CBT) ini belum cukup dalam menentukan peserta yang memperoleh nilai terbaik. Algoritma Profile Matching dipilih sebagai algoritma yang dapat membantu dalam pengambilan keputusan. Terdapat 5 kriteria yang digunakan, yaitu nilai CBT dan penghasilan orang tua sebagai kriteria jenis Core Factor, nilai UN matematika, nilai UN Bahasa Inggris, dan nilai UN Bahasa Indonesia sebagai kriteria jenis Secondary Factor. Pengujian dilakukan dengan membandingkan hasil perhitungan pada sistem dan perhitungan excel di mana terdapat 3 nilai Core Factor dan Secondary Factor yang berbeda. Terjadi ketidaksesuaian pada hasil pengujian ketika beberapa profil memiliki nilai akhir yang sama. Salah satunya, Dea Nur Alifah dan Rahma Nurlita dengan nilai CF 60\%, SF 40\% dan CF 70\%, SF $30 \%$ memiliki nilai akhir sebesar 5.78, berada pada urutan 3 dan 4. Selanjutnya pada nilai CF $80 \%$ dan SF $20 \%$ keduanya mengalami penurunan nilai, menjadi 5.77 serta masih berada di urutan 3 dan 4 . Penerapan 
algoritma Profile Matching dengan output berupa pemeringkatan (ranking) atau pengurutan nilai dalam aplikasi Computer Based Test (CBT) ini masih belum optimal.

\section{Kata Kunci: Algoritma Pemeringkatan; Computer Based Test (CBT); Profile Matching; Sistem Pendukung Keputusan}

\section{Pendahuluan}

Sekolah Tinggi Ilmu Kesehatan (STIKes) Kuningan merupakan salah satu perguruan tinggi swasta yang sudah berdiri sejak tahun 2006 . Sampai saat ini program studi yang tersedia sebanyak 6 program studi yaitu D3 Kebidanan, S1 Kebidanan, S1 Kesehatan Masyarakat, S1 Keperawatan, Profesi Ners, Profesi Bidan dan S2 Kesehatan Masyarakat.

Penerimaan mahasiswa baru merupakan salah satu proses yang dilakukan di sebuah perguruan tinggi guna mendapatkan calon-calon mahasiswa terpilih sesuai kriteria yang ditentukan. Terdapat 3 tahapan dalam pelaksanaan Penerimaan Mahasiswa Baru melalui jalur umum yaitu tes wawancara, tes kesehatan, dan tes tulis yang masih dilakukan secara manual.

Dalam melaksanakan tes tulis tersebut, STIKes Kuningan belum menggunakan sistem terkomputerisasi. Sehingga pelaksanaan ujian yang dilakukan secara manual menjadi kendala dalam proses pelaksanaan ujian serta skoring data nilai yang dihasilkan.

Berdasarkan uraian permasalahan, diperlukan adanya sebuah sistem untuk pelaksanaan ujian secara terkomputerisasi yang disertai dengan penerapan sebuah algoritma pemeringkatan yaitu algoritma profile matching sehingga dapat membantu proses pelaksanaan ujian dalam Penerimaan Mahasiswa Baru.

Adapun beberapa penelitian terdahulu yang diteliti berjudul "Penerapan Algoritma Fisher Yates Shuffle Pada Computer Based Test (CBT) Untuk Ujian Sekolah Di SMKN 1 Payung" didapatkan hasil dari penelitian tersebut bahwa algoritma yang digunakan bertujuan untuk meminimalisir kecurangan saat proses ujian berlangsung karena penelitian tersebut berfokus pada pengacakkan soal ujian yang digunakan, namun pada pengolahan data nilai belum diterapkan sebuah algoritma (Putra \& Sugihartono, 2019).

Kemudian penelitian sebelumnya yang berjudul "Implementasi Metode Profile Matching Dalam Aplikasi Penerimaan Siswa Baru pada SMK Ma'arif NU 2 Boyolali”. Didapatkan kesimpulan bahwa proses penerimaan siswa baru yang dilaksanakan sudah berbasis online. Akan tetapi terdapat kendala dalam penentuan calon siswa dinyatakan lulus atau tidak masih dilakukan secara manual sehingga belum optimal. Data uji yang digunakan dalam perhitungan hanya menggunakan 2 data uji sehingga tingkat akurasi yang dihasilkan sangat baik. Dan menyimpulkan bahwa algoritma profile matching mampu memberikan alternatif keputusan dalam menentukan peringkat pendaftar siswa baru pada SMK Ma'arif NU 2 Boyolali (Prabowo \& Suprapto, 2019).

Berdasarkan seluruh uraian tersebut, masih terdapat peluang pengembangan penelitian tentang sebuah sistem ujian dalam seleksi mahasiswa baru pada proses skoring yang disertai dengan penerapan algoritma pemeringkatan yaitu algoritma profile matching dengan mengacu pada kriteria yang digunakan.

Penelitian ini dilakukan dengan tujuan untuk membangun aplikasi Computer Based Test (CBT) dalam seleksi mahasiswa baru serta mengukur tingkat akurasi skoring yang dihasilkan dengan mengacu pada beberapa kriteria yang digunakan. Sehingga dapat menjadi solusi dalam menangani proses seleksi mahasiswa baru serta memudahkan dalam pengolahan data nilai peserta calon mahasiswa baru.

\section{Landasan Teori}

\subsection{Computer Based Test (CBT)}

Tes berbasis komputer adalah tes atau ujian yang dilaksanakan menggunakan komputer. Karakteristik dari tes ini yaitu menggunakan 1 perangkat tes atau ujian untuk beberapa peserta. (Hariyanto, 2017, p. 2)

\subsection{Sistem Pendukung Keputusan}

Sistem pendukung keputusan yang dibangun bertujuan untuk mendukung solusi dari permasalahan yang ada. Aplikasi sistem pendukung keputusan lebih fleksibel, interaktif dan dapat di adaptasi yang dikembangkan untuk pengambilan keputusan atas masalah manajemen spesifik yang tidak terstruktur. (Nofriansyah, 2017, p. 2)

\subsection{Algoritma Profile Matching}

Profile Matching adalah sebuah algoritma yang sederhana dalam sistem pendukung 
keputusan di mana terdapat perbandingan nilai GAP antara nilai alternative dan kriteria. Terdapat tabel nilai bobot GAP yang menjadi acuan dalam perhitungan atau analisis GAP. Analisis GAP harus memahami konsep skala prioritas karena dalam pembobotan terdapat skala nilai atau range yang digunakan berdasarkan prioritas setiap kriteria. (Nofriansyah \& Defit, 2017, p. 49)

\section{Metodologi Penelitian}

Metodologi penelitian yang akan dilakukan terletak pada gambar 1 berikut:

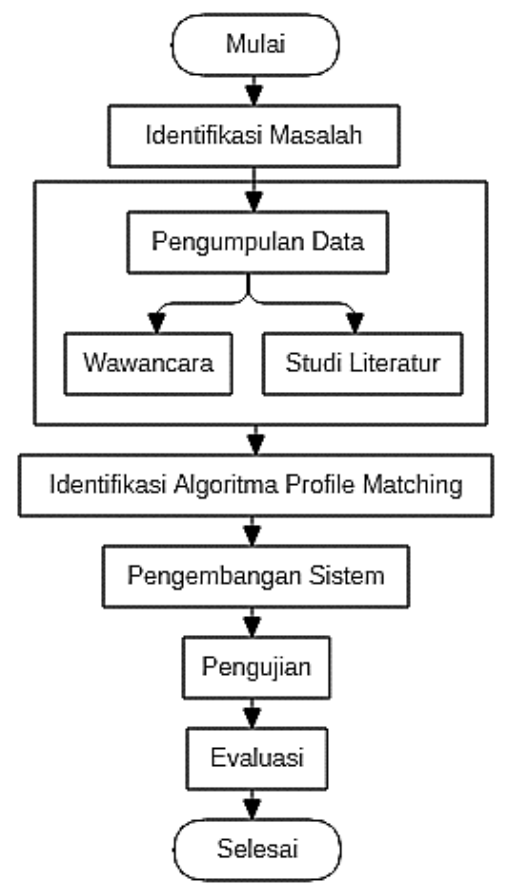

Gambar 1. Metodologi Penelitian

\subsection{Identifikasi Masalah}

Identifikasi masalah adalah langkah pertama yang dilakukan melalui proses pengenalan atau pengamatan terhadap tempat studi kasus untuk mengetahui permasalahan yang dapat dijadikan topik penelitian.

\subsection{Pengumpulan Data}

Pengumpulan data terdiri dari 2 cara yaitu:

a. Wawancara, dilakukan melalui komunikasi secara lisan meliputi tanya jawab dengan pihak yang bersangkutan.

b. Studi literatur, dilakukan dengan mempelajari referensi lain seperti artikel di internet, jurnal penelitian serta dokumen internal yang berkaitan dengan topik penelitian.

\subsection{Identifikasi Algoritma Profile Matching}

Identifikasi algoritma profile matching merupakan tahap mengidentifikasi terhadap cara kerja dari algoritma tersebut. Adapun tahapan proses perhitungan algoritma profile matching yaitu:

a. Penentuan kriteria yang akan digunakan

b. Penentuan bobot dari masing-masing kriteria yang digunakan

c. Pemetaan nilai GAP

d. Menghitung rata-rata nilai core factor dan rata-rata nilai secondary factor

e. Melakukan pemeringkatan atau pengurutan nilai

\subsection{Pengembangan Sistem}

Metode pengembangan sistem yang digunakan yaitu Extreme Programming.

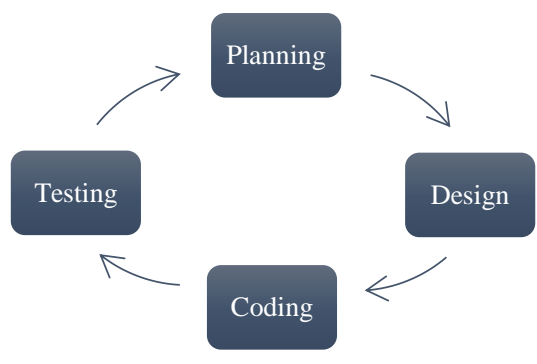

Gambar 2. Extreme Programming

Extreme Programming (XP) merupakan suatu pendekatan paling banyak digunakan untuk mengembangkan perangkat lunak cepat. (Pressman, Ph.D., 2012).

Tahapan pengembangan perangkat lunak dengan Extreme Programming (XP) meliputi:

a. Planning

Tahapan planning dilakukan untuk mendapatkan gambaran umum dari apliaksi yang akan dibangun.

b. Design

Tahapan design dalam pengembangan aplikasi dilakukan untuk mengatur pola logika dalam sistem.

c. Coding

Tahapan ini dilakukan pembuatan script program dari setiap design atau rancangan yang sudah dibuat sebelumnya.

d. Testing

Tahap testing merupakan tahap uji coba yang dilakukan setelah tahapan coding 
selesai. Testing dilakukan dengan tujuan untuk mengetahui kesahalan atau kekurangan dari aplikasi yang dibangun.

\subsection{Pengujian}

Pengujian dilakukan untuk menguji algoritma profile matching yang tertera pada proses skoring dari hasil ujian yang dilakukan dengan mengacu pada beberapa kriteria yang digunakan. Pengujian dilakukan dengan mengukur tingkat akurasi dari hasil yang dilakukan oleh sistem dengan proses perhitungan menggunakan Microsoft excel.

\subsection{Evaluasi}

Tahapan ini merupakan tahap evaluasi dari tahapan-tahapan yang telah dilakukan sebagai dasar dalam membuat kesimpulan dari penelitian yang dilakukan.

\section{Hasil dan Pembahasan \\ 4.1 Pengumpulan Data}

Proses pengumpulan data diawali dengan proses tanya jawab dengan panitia penyelenggara penerimaan mahasiswa baru di Sekolah Tinggi Ilmu Kesehatan (STIKes) Kuningan yang menghasilkan informasi bahwa proses seleksi mahasiswa baru dilakukan secara manual tanpa bantuan sistem atau aplikasi apapun. Dan juga proses penilaian dari hasil seleksi menghabiskan waktu yang lama sehingga hasil seleksi tidak segera tersampaikan ke peserta.

\subsection{Identifikasi Algoritma Profile Matching}

Proses identifikasi algoritma dilakukan dengan tahapan-tahapan berikut:

1. Menentukan kriteria

Terdapat 5 kriteria yang digunakan, yaitu:

Tabel 1. Kriteria

\begin{tabular}{|c|c|c|}
\hline $\begin{array}{l}\text { Kode } \\
\text { Kriteria }\end{array}$ & Kriteria & $\begin{array}{c}\text { Jenis } \\
\text { Kriteria }\end{array}$ \\
\hline A1 & Nilai CBT & \multirow{2}{*}{ Core Factor } \\
\hline A2 & Penghasilan Orang Tua & \\
\hline $\mathbf{A 3}$ & Nilai UN Matematika & \multirow{3}{*}{$\begin{array}{l}\text { Secondary } \\
\text { Factor }\end{array}$} \\
\hline A4 & Nilai UN B. Inggris & \\
\hline A5 & Nilai UN B. Indonesia & \\
\hline
\end{tabular}

Tabel 1 merupakan kriteria yang digunakan dalam perhitungan algoritma profile matching. Kode kriteria A1 dan A2 menjadi kriteria jenis core factor atau faktor utama, dan kode kriteria A3, A4, A5 menjadi kriteria jenis secondary factor atau faktor pendukung.
2. Pembobotan Kriteria

Pembobotan untuk masing-masing kriteria yang digunakan, yaitu:

Tabel 2. Pembobotan

\begin{tabular}{ccc}
\hline Bobot & Skala Nilai & Keterangan \\
\hline $\mathbf{1}$ & $0-59$ & Sangat Kurang \\
\hline $\mathbf{2}$ & $60-69$ & Kurang \\
\hline $\mathbf{3}$ & $70-79$ & Cukup \\
\hline $\mathbf{4}$ & $80-89$ & Baik \\
\hline $\mathbf{5}$ & $90-100$ & Sangat Baik \\
\hline
\end{tabular}

Pembobotan untuk kriteria Penghasilan Orang Tua yaitu:

Tabel 3. Pembobotan Penghasilan Orang Tua

\begin{tabular}{ccc}
\hline Bobot & Skala Nilai & Keterangan \\
\hline $\mathbf{1}$ & $<$ Rp. 500.000 & Sangat Kurang \\
\hline $\mathbf{2}$ & $\begin{array}{c}>\text { Rp. } 500.000- \\
\text { Rp. } 1.000 .000\end{array}$ & Kurang \\
\hline $\mathbf{3}$ & $\begin{array}{c}>\text { Rp. } 1.000 .000- \\
\text { Rp. } 2.500 .000\end{array}$ & Cukup \\
\hline $\mathbf{4}$ & $\begin{array}{c}>\text { Rp. } 2.500 .000- \\
\text { Rp. } 5.000 .000\end{array}$ & Baik \\
\hline $\mathbf{5}$ & $>$ Rp. 5.000 .000 & Sangat Baik \\
\hline
\end{tabular}

Tabel 2 dan tabel 3 merupakan pembobotan kriteria yang digunakan. Di mana terdapat 5 skala nilai yaitu sangat kurang, kurang, baik dan sangat baik. Pembobotan kriteria ini dilakukan untuk pemetaan bobot nilai dari masing-masing profil.

3. Bobot Nilai GAP

Berikut adalah bobot nilai GAP yang digunakan:

Tabel 4. Bobot Nilai GAP (Nofriansyah \& Defit, 2017)

\begin{tabular}{ccc}
\hline $\begin{array}{c}\text { Selisih } \\
\text { (GAP) }\end{array}$ & $\begin{array}{c}\text { Nilai } \\
\text { Bobot }\end{array}$ & $\begin{array}{c}\text { Keterangan } \\
\text { Tidak ada Selisih (Profil Individu } \\
\text { sesuai yang dibutuhkan) }\end{array}$ \\
\hline 0 & 6 & Profil individu kelebihan 1 tingkat \\
\hline 1 & 5.5 & Profil individu kekurangan 1 tingkat \\
\hline-1 & 5 & Profil individu kelebihan 2 tingkat \\
\hline 2 & 4.5 & Profil individu kekurangan 2 tingkat \\
\hline-2 & 4 & Profil individu kelebihan 3 tingkat \\
\hline 3 & 3.5 & Profil individu kekurangan 3 tingkat \\
\hline-3 & 3 & Profil individu kelebihan 4 tingkat \\
\hline 4 & 2.5 & Profil individu kekurangan 4 tingkat \\
\hline-4 & 2 & Profil individu kelebihan 5 tingkat \\
\hline 5 & 1.5 &
\end{tabular}

Tabel 4 berisi bobot nilai GAP yang menjadi acuan dalam pemetaan nilai GAP dan pembobotan dari masing-masing profil. 
4. Pemetaan Nilai GAP dan Pembobotan

Pemetaan GAP adalah perbedaan atau selisih antara penilaian profile individu dengan profil nilai standar atau ideal yang digunakan. Pemetaan GAP dilakukan dengan rumus berikut:

$$
\begin{aligned}
G A P & =\text { Profil Alternatif } \\
& - \text { Profil Kriteria }
\end{aligned}
$$

5. Menghitung Nilai Core Factor dan Secondary Factor

a. Core factor

Kriteria penilaian core factor adalah Nilai CBT dan Penghasilan Orang Tua. Rumus yang digunakan adalah sebagai berikut:

$$
N C F=\frac{\sum N C(c, u, p)}{\sum I C}
$$

Keterangan:

NCF: Nilai rata-rata core factor

$\mathrm{NC}(\mathrm{c}, \mathrm{u}, \mathrm{p})$ : Jumlah total nilai core factor

IC: jumlah item core factor

\section{b. Secondary factor}

Nilai UN Matematika, Nilai UN Bahasa Inggris dan Nilai UN Bahasa Indonesia merupakan kriteria secondary factor. Perhitungan dilakukan dengan menggunakan rumus berikut:

$$
N S F=\frac{\sum N S(c, u, p)}{\sum I S}
$$

Keterangan:

NSF: Nilai rata-rata secondary factor

NS (c, u, p): jumlah total nilai secondary factor IS: jumlah item secondary factor

6. Pemeringkatan

Proses pemeringkatan dilakukan dengan mengurutkan nilai terbesar sampai nilai yang terkecil.

\subsection{Pengembangan Sistem}

\section{Planning}

Sekolah Tinggi Ilmu Kesehatan Kuningan membutuhkan sebuah sistem ujian dalam proses seleksi mahasiswa baru yang disertai dengan penerapan algoritma pemeringkatan yaitu algoritma profile matching sebagai sistem pendukung keputusan dalam proses skoring data ujian tersebut.

2. Design

\section{a. Use Case Diagram}

Use case diagram menggambarkan interaksi aktor dengan dengan sistem. Use case diagram admin memiliki hak akses penuh terhadap sistem tertera pada gambar 2 berikut:

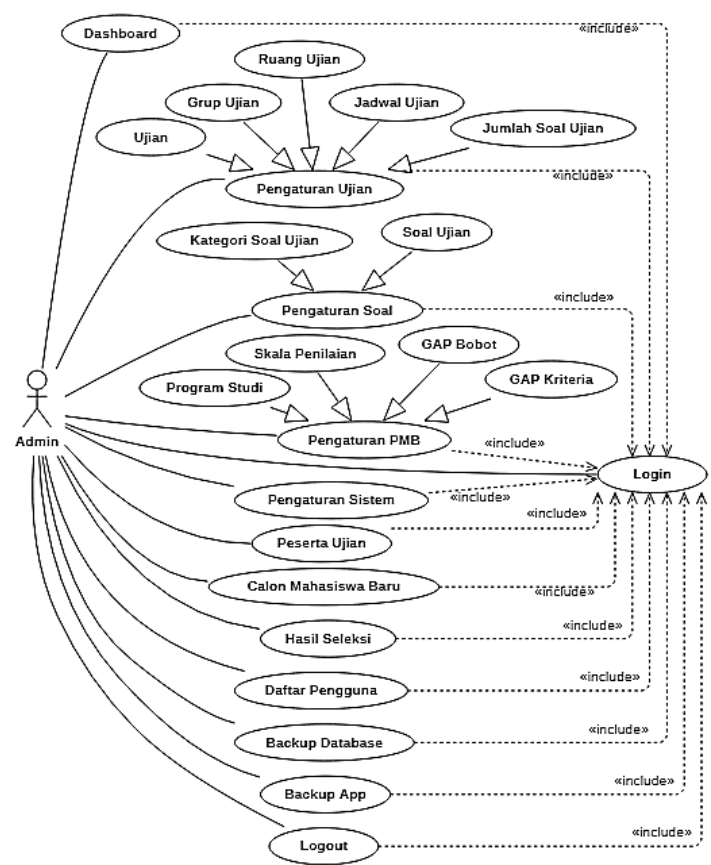

Gambar 3. Use Case Diagram Admin

Gambar 3 mendeskripsikan interaksi aktor admin dengan aplikasi yang memiliki akses penuh. Setiap usecase mewakili semua menu yang ada pada aplikasi dengan tipe pengguna admin.

\section{b. Class Diagram \\ Class diagram menggambarkan} atribut dan operation setiap kelas dalam sebuah sistem dan hubungannya antara satu dengan lainnya. 


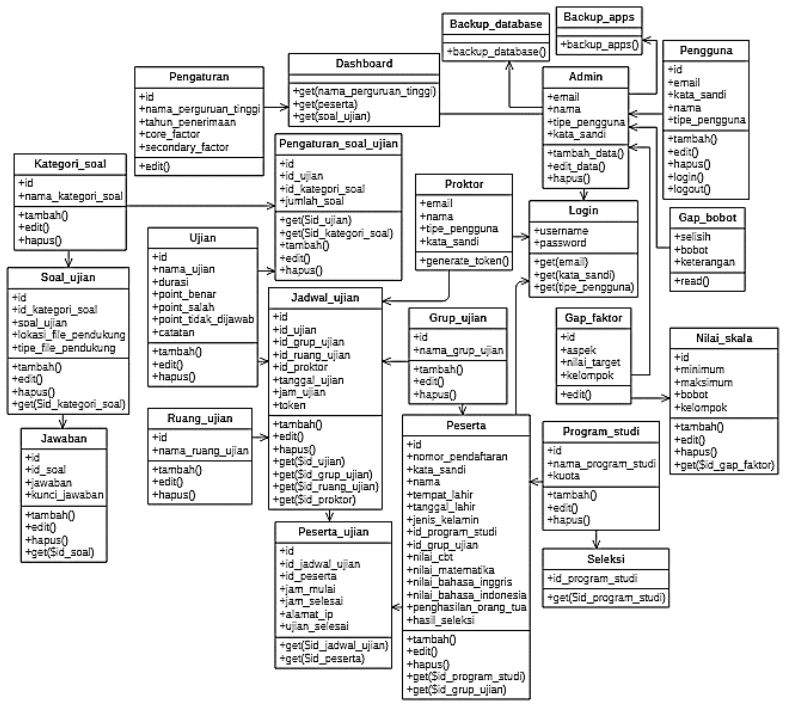

Gambar 4. Class Diagram

Gambar 4 merupakan atribut dan operation setiap kelas yang ada pada aplikasi di mana terdapat 21 kelas yang saling berhubungan antar 1 dengan yang lainnya.

\section{Coding}

Kode program dari proses perhitungan algoritma profile matching terdapat dalam menu Hasil Seleksi dengan tipe pengguna Admin. Ketika admin memilih menu Hasil Seleksi dan memilih salah satu program studi yang akan ditampilkan nilai akhirnya, sistem akan menjalankan fungsi set_nilai_akhir dan melakukan perhitungan dari algoritma profile matching, selanjutnya sistem akan menampilkan hasil akhir dari program studi yang dipilih.

\section{Testing}

a. Pengujian Menu Hasil Seleksi

Pengujian pada menu Hasil Seleksi yang dilakukan dengan menjalankan kondisi percobaan yang tertera pada tabel berikut:

Tabel 5. Pengujian Menu Hasil Seleksi

\begin{tabular}{cccc}
\hline \multicolumn{4}{c}{ Kasus dan Hasil Uji } \\
$\begin{array}{c}\text { Data } \\
\text { Masukan }\end{array}$ & $\begin{array}{c}\text { Yang } \\
\text { Diharapkan }\end{array}$ & Pengamatan & Kesimpulan \\
\hline Pilih & Tampilkan & Menampilkan & Diterima \\
Program & hasil seleksi & hasil seleksi & \\
Studi & sesuai & sesuai & \\
& program & program & \\
& studi yang & studi yang & \\
& dipilih. & dipilih. & \\
& & &
\end{tabular}

\subsection{Pengujian}

Pada tahapan pengujian menggunakan data uji sebanyak 33 data peserta dari program studi S1 Keperawatan. Data uji dapat dilihat pada tabel 6 berikut:

Tabel 6. Data Uji

\begin{tabular}{|c|c|c|c|c|c|c|}
\hline \multirow[t]{2}{*}{ No. } & \multirow[t]{2}{*}{ Nama } & \multicolumn{5}{|c|}{ Kriteria } \\
\hline & & A1 & A2 & $\mathbf{A 3}$ & A4 & A5 \\
\hline 1. & $\begin{array}{l}\text { Agus Haerul } \\
\text { Sugus }\end{array}$ & 77 & 2.000 .000 & 50 & 50 & 75 \\
\hline 2. & $\begin{array}{c}\text { Ajeng } \\
\text { Charisma } \\
\text { Shandy } \\
\text { Fadhilah S. }\end{array}$ & 94 & 4.000 .000 & 75 & 80 & 80 \\
\hline 3. & $\begin{array}{c}\text { Billy } \\
\text { Prambudi }\end{array}$ & 93 & 6.000 .000 & 78 & 80 & 80 \\
\hline 4. & $\begin{array}{l}\text { Dea Nur } \\
\text { Alifah }\end{array}$ & 95 & 3.000 .000 & 75 & 77 & 87 \\
\hline 5. & $\begin{array}{l}\text { Dea Putri } \\
\text { Mulyani }\end{array}$ & 63 & 5.000 .000 & 77 & 79 & 83 \\
\hline 6. & $\begin{array}{c}\text { Fahri } \\
\text { Maulana }\end{array}$ & 64 & 1.500 .000 & 72 & 69 & 80 \\
\hline 7. & $\begin{array}{l}\text { Hilda } \\
\text { Rahma } \\
\text { Aulita }\end{array}$ & 97 & 5.000 .000 & 60 & 60 & 75 \\
\hline 8. & $\begin{array}{c}\text { Ika } \\
\text { Ruliyanti } \\
\text { Rukmana }\end{array}$ & 81 & 3.000 .000 & 62 & 78 & 80 \\
\hline 9. & Ismi Santika & 58 & 500.000 & 78 & 79 & 82 \\
\hline 10. & $\begin{array}{c}\text { Kartika Eka } \\
\text { Cahyani }\end{array}$ & 94 & 4.000 .000 & 79 & 80 & 84 \\
\hline 11. & $\begin{array}{l}\text { Lidya } \\
\text { Elisabet } \\
\text { Lubis }\end{array}$ & 50 & 3.000 .000 & 80 & 90 & 85 \\
\hline 12. & $\begin{array}{l}\text { Mordenaya } \\
\text { Natalisa L. }\end{array}$ & 67 & 3.000 .000 & 79 & 80 & 84 \\
\hline 13. & $\begin{array}{l}\text { Muhamad } \\
\text { Bagja P. }\end{array}$ & 62 & 3.000 .000 & 79 & 81 & 83 \\
\hline 14. & $\begin{array}{l}\text { Muhammad } \\
\text { Reno F. }\end{array}$ & 94 & 4.000 .000 & 80 & 81 & 85 \\
\hline 15. & $\begin{array}{c}\text { Nabilah } \\
\text { Siska } \\
\text { Fitriyah }\end{array}$ & 90 & 1.750 .000 & 83 & 83 & 84 \\
\hline 16. & $\begin{array}{l}\text { Nadia } \\
\text { Yulliar }\end{array}$ & 60 & 1.500 .000 & 86 & 60 & 76 \\
\hline 17. & $\begin{array}{l}\text { Neneng } \\
\text { Nuraeni }\end{array}$ & 70 & 1.500 .000 & 82 & 79 & 81 \\
\hline 18. & $\begin{array}{c}\text { Nida } \\
\text { Nurjannah }\end{array}$ & 66 & 7.000 .000 & 72 & 83 & 87 \\
\hline 19. & $\begin{array}{l}\text { Nur Adinda } \\
\text { Putri A. }\end{array}$ & 82 & 1.750 .000 & 40 & 46 & 82 \\
\hline 20. & $\begin{array}{l}\text { Pipih } \\
\text { Napilah }\end{array}$ & 75 & 1.000 .000 & 33 & 40 & 63 \\
\hline 21. & $\begin{array}{l}\text { Puput } \\
\text { Melati }\end{array}$ & 66 & 3.000 .000 & 80 & 78 & 79 \\
\hline 22. & $\begin{array}{l}\text { Rahma } \\
\text { Nurlita }\end{array}$ & 94 & 3.000 .000 & 78 & 79 & 80 \\
\hline 23. & $\begin{array}{c}\text { Rani } \\
\text { Nurlaela }\end{array}$ & 100 & 1.000 .000 & 85 & 85 & 86 \\
\hline 24. & Reka Apista & 97 & 3.000 .000 & 70 & 70 & 75 \\
\hline 25. & Rifki Fadli & 78 & 2.000 .000 & 55 & 67 & 64 \\
\hline
\end{tabular}




\begin{tabular}{ccccccc}
\hline 26. & $\begin{array}{c}\text { Rima } \\
\text { Sukma } \\
\text { Wijaya }\end{array}$ & 82 & 300.000 & 75 & 83 & 80 \\
\hline 27. & $\begin{array}{c}\text { Riska } \\
\text { Anggraeni }\end{array}$ & 79 & 2.500 .000 & 78 & 78 & 80 \\
\hline 28. & $\begin{array}{c}\text { Siti Lutfiah } \\
\text { Hasyim }\end{array}$ & 70 & 2.000 .000 & 85 & 80 & 89 \\
\hline 29. & $\begin{array}{c}\text { Susi } \\
\text { Susilawati }\end{array}$ & 57 & 3.000 .000 & 80 & 80 & 80 \\
\hline 30. & $\begin{array}{c}\text { Tita } \\
\text { Nuratiyyah }\end{array}$ & 63 & 2.000 .000 & 80 & 80 & 80 \\
\hline 31. & $\begin{array}{c}\text { Vina Dwi } \\
\text { Astuti }\end{array}$ & 90 & 3.000 .000 & 82 & 83 & 85 \\
\hline 32. & $\begin{array}{c}\text { Walis } \\
\text { Awaliyah }\end{array}$ & 66 & 2.000 .000 & 80 & 80 & 80 \\
\hline 33. & $\begin{array}{c}\text { Widia } \\
\text { Nopiani } \\
\text { Putri }\end{array}$ & 52 & 1.500 .000 & 80 & 80 & 85 \\
\hline & & & & & \\
\hline
\end{tabular}

Tabel 6 merupakan 33 data uji dari program studi S1 Keperawatan dengan nilai-nilai yang belum dilakukan pemetaan.

1. Pemetaan Nilai GAP dan Pembobotan Dalam pemetaan Nilai GAP, nilai standar yang digunakan yaitu:

Tabel 7. Nilai Standar

\begin{tabular}{ccc}
\hline $\begin{array}{c}\text { Kode } \\
\text { Kriteria }\end{array}$ & Nama Kriteria & $\begin{array}{c}\text { Nilai } \\
\text { Standar }\end{array}$ \\
\hline A1 & Nilai CBT & 4 \\
\hline A2 & Penghasilan Orang Tua & 4 \\
\hline A3 & Nilai UN Matematika & 3 \\
\hline A4 & Nilai UN B. Inggris & 3 \\
\hline A5 & Nilai UN B. Indonesia & 3 \\
\hline
\end{tabular}

Tabel 7 berisi nilai standar atau nilai target yang harus dipenuhi dari setiap profil. A1, A2 dengan nilai 4 dan A3, A4, A5 dengan nilai 3. berikut:

Pemetaan nilai GAP tertera pada tabel 8

Tabel 8. Pemetaan Nilai GAP

\begin{tabular}{|c|c|c|c|c|c|c|}
\hline \multirow{2}{*}{ No. } & \multirow{2}{*}{ Nama } & \multicolumn{5}{|c|}{ Kriteria } \\
\hline & & A1 & A2 & A3 & A4 & A5 \\
\hline 1. & Agus Haerul Sugus & 3 & 3 & 1 & 1 & 3 \\
\hline 2. & $\begin{array}{c}\text { Ajeng Charisma } \\
\text { Shandy Fadhilah S. }\end{array}$ & 5 & 4 & 3 & 4 & 4 \\
\hline 3. & Billy Prambudi & 5 & 5 & 3 & 4 & 4 \\
\hline 4. & Dea Nur Alifah & 5 & 4 & 3 & 3 & 4 \\
\hline 5. & Dea Putri Mulyani & 2 & 5 & 3 & 3 & 4 \\
\hline 6. & Fahri Maulana & 2 & 3 & 3 & 2 & 4 \\
\hline 7. & Hilda Rahma Aulita & 5 & 5 & 2 & 2 & 3 \\
\hline 8. & $\begin{array}{c}\text { Ika Ruliyanti } \\
\text { Rukmana }\end{array}$ & 4 & 4 & 2 & 3 & 4 \\
\hline 9. & Ismi Santika & 1 & 1 & 3 & 3 & 3 \\
\hline 10. & $\begin{array}{c}\text { Kartika Eka } \\
\text { Cahyani }\end{array}$ & 5 & 4 & 3 & 4 & 4 \\
\hline
\end{tabular}

\begin{tabular}{ccccccc}
\hline 11. & $\begin{array}{c}\text { Lidya Elisabet } \\
\text { Lubis }\end{array}$ & 1 & 4 & 4 & 5 & 4 \\
\hline 12. & $\begin{array}{c}\text { Mordenaya Natalisa } \\
\text { L. }\end{array}$ & 2 & 4 & 3 & 4 & 4 \\
\hline
\end{tabular}

\begin{tabular}{ccccccc}
\hline 13. & Muhamad Bagja P. & 2 & 4 & 3 & 4 & 4 \\
\hline 14. & Muhammad Reno F. & 5 & 4 & 4 & 4 & 4 \\
\hline 15. & $\begin{array}{c}\text { Nabilah Siska } \\
\text { Fitriyah }\end{array}$ & 5 & 3 & 4 & 4 & 4
\end{tabular}

\begin{tabular}{ccccccc}
\hline 16. & Nadia Yulliar & 2 & 3 & 4 & 2 & 3 \\
\hline 17. & Neneng Nuraeni & 3 & 3 & 4 & 3 & 4 \\
\hline 18. & Nida Nurjannah & 2 & 5 & 3 & 4 & 4 \\
\hline 19. & Nur Adinda Putri A. & 4 & 3 & 1 & 1 & 4 \\
\hline 20. & Pipih Napilah & 3 & 2 & 1 & 1 & 2 \\
\hline 21. & Puput Melati & 2 & 4 & 4 & 3 & 3 \\
\hline 22. & Rahma Nurlita & 5 & 4 & 3 & 3 & 4 \\
\hline 23. & Rani Nurlaela & 5 & 2 & 4 & 4 & 4 \\
\hline 24. & Reka Apista & 5 & 4 & 3 & 3 & 3 \\
\hline 25. & Rifki Fadli & 3 & 3 & 1 & 2 & 2 \\
\hline 26. & Rima Sukma & 4 & 1 & 3 & 4 & 4
\end{tabular}

\begin{tabular}{ccccccc} 
26. & $\begin{array}{c}\text { Rima Sukma } \\
\text { Wijaya }\end{array}$ & 4 & 1 & 3 & 4 & 4 \\
\hline 27. & Riska Anggraeni & 3 & 3 & 3 & 3 & 4
\end{tabular}

\begin{tabular}{ccccccc}
27. & Riska Anggraeni & 3 & 3 & 3 & 3 & 4 \\
\hline 28. & Siti Lutfiah Hasyim & 3 & 3 & 4 & 4 & 4 \\
\hline 29. & Susi Susilawati & 1 & 4 & 4 & 4 & 4 \\
\hline
\end{tabular}

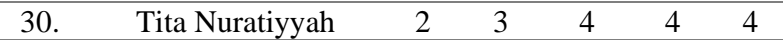

\begin{tabular}{|c|c|c|}
\hline 31 & Vina Dwi Astuti & \\
\hline
\end{tabular}

\begin{tabular}{lclllll} 
32. & Walis Awaliyah & 3 & 3 & 4 & 4 & 4 \\
\hline 33. & Widia Nopiani Putri & 1 & 4 & 4 & 4 & 4
\end{tabular}

\begin{tabular}{|llllll} 
PROFILE STANDAR & $\mathbf{4}$ & $\mathbf{4}$ & $\mathbf{3}$ & $\mathbf{3}$ & $\mathbf{3}$ \\
\hline
\end{tabular}

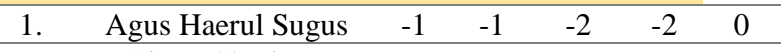

$\begin{array}{cccccccc}\text { 2. } & \text { Ajeng Charisma } & 1 & 0 & 0 & 1 & 1\end{array}$

\begin{tabular}{ccccccc}
\hline 3. & Billy Prambudi & 1 & 1 & 0 & 1 & 1 \\
\hline 4. & Dea Nur Alifah & 1 & 0 & 0 & 0 & 1 \\
\hline 5. & Dea Putri Mulyani & -2 & 1 & 0 & 0 & 1 \\
\hline 6. & Fahri Maulana & -2 & -1 & 0 & -1 & 1 \\
\hline 7. & Hilda Rahma Aulita & 1 & 1 & -1 & -1 & 0 \\
\hline 8. & $\begin{array}{c}\text { Ika Ruliyanti } \\
\text { Rukmana }\end{array}$ & 0 & 0 & -1 & 0 & 1 \\
\hline 9. & Ismi Santika & -3 & -3 & 0 & 0 & 0 \\
\hline 10. & $\begin{array}{c}\text { Kartika Eka } \\
\text { Cahyani }\end{array}$ & 1 & 0 & 0 & 1 & 1 \\
\hline 11. & $\begin{array}{c}\text { Lidya Elisabet } \\
\text { Lubis }\end{array}$ & -3 & 0 & 1 & 2 & 1 \\
\hline
\end{tabular}

$\begin{array}{ccccccc}\text { 12. Mordenaya Natalisa } & -2 & 0 & 0 & 1 & 1\end{array}$

$\begin{array}{ccccccc}\text { 13. Muhamad Bagja P. } & -2 & 0 & 0 & 1 & 1 \\ \text { 14. Muhammad Reno F. } & 1 & 0 & 1 & 1 & 1\end{array}$

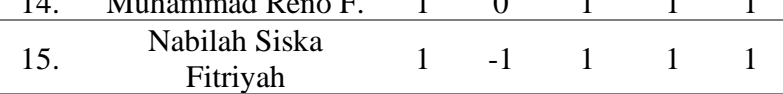

\begin{tabular}{|c|c|c|c|c|c|c|}
\hline 16. & Nadia Yulliar & -2 & -1 & 1 & -1 & 0 \\
\hline 17. & Neneng Nuraeni & -1 & 1 & 1 & 0 & 1 \\
\hline 18. & Nida Nurjannah & -2 & 1 & 0 & 1 & 1 \\
\hline 19. & Nur Adinda Putri A. & 0 & -1 & -2 & -2 & 1 \\
\hline 20. & Pipih Napilah & -1 & -2 & -2 & -2 & -1 \\
\hline 21. & Puput Melati & -2 & 0 & 1 & 0 & 0 \\
\hline 22. & Rahma Nurlita & 1 & 0 & 0 & 0 & 1 \\
\hline 23. & Rani Nurlaela & 1 & -2 & 1 & 1 & 1 \\
\hline 24. & Reka Apista & 1 & 0 & 0 & 0 & 0 \\
\hline 25. & Rifki Fadli & -1 & -1 & -2 & -1 & -1 \\
\hline 26. & $\begin{array}{l}\text { Rima Sukma } \\
\text { Wijaya }\end{array}$ & 0 & -3 & 0 & 1 & 1 \\
\hline 27. & Riska Anggraeni & -1 & -1 & 0 & 0 & 1 \\
\hline 28. & Siti Lutfiah Hasyim & -1 & -1 & 1 & 1 & 1 \\
\hline
\end{tabular}




\begin{tabular}{ccccccc}
\hline 29. & Susi Susilawati & -3 & 0 & 1 & 1 & 1 \\
\hline 30. & Tita Nuratiyyah & -2 & -1 & 1 & 1 & 1 \\
\hline 31. & Vina Dwi Astuti & 1 & -1 & 1 & 1 & 1 \\
\hline 32. & Walis Awaliyah & -2 & -1 & 1 & 1 & 1 \\
\hline 33. & Widia Nopiani Putri & -3 & -1 & 1 & 1 & 1
\end{tabular}

Tabel 8 merupakan tahapan pertama dalam perhitungan algoritma yaitu melakukan pemetaan nilai terhadap masing-masing profil dengan mengurangi nilai profil dengan nilai standar yang sudah ditentukan.

Setelah diperoleh hasil dari pemetaan nilai GAP pada data uji, selanjutnya setiap profil diberikan bobot nilai dengan mengacu pada tabel 4 . Maka hasil dari pembobotan dari setiap profil tertera pada tabel 9 berikut:

Tabel 9. Hasil Pembobotan

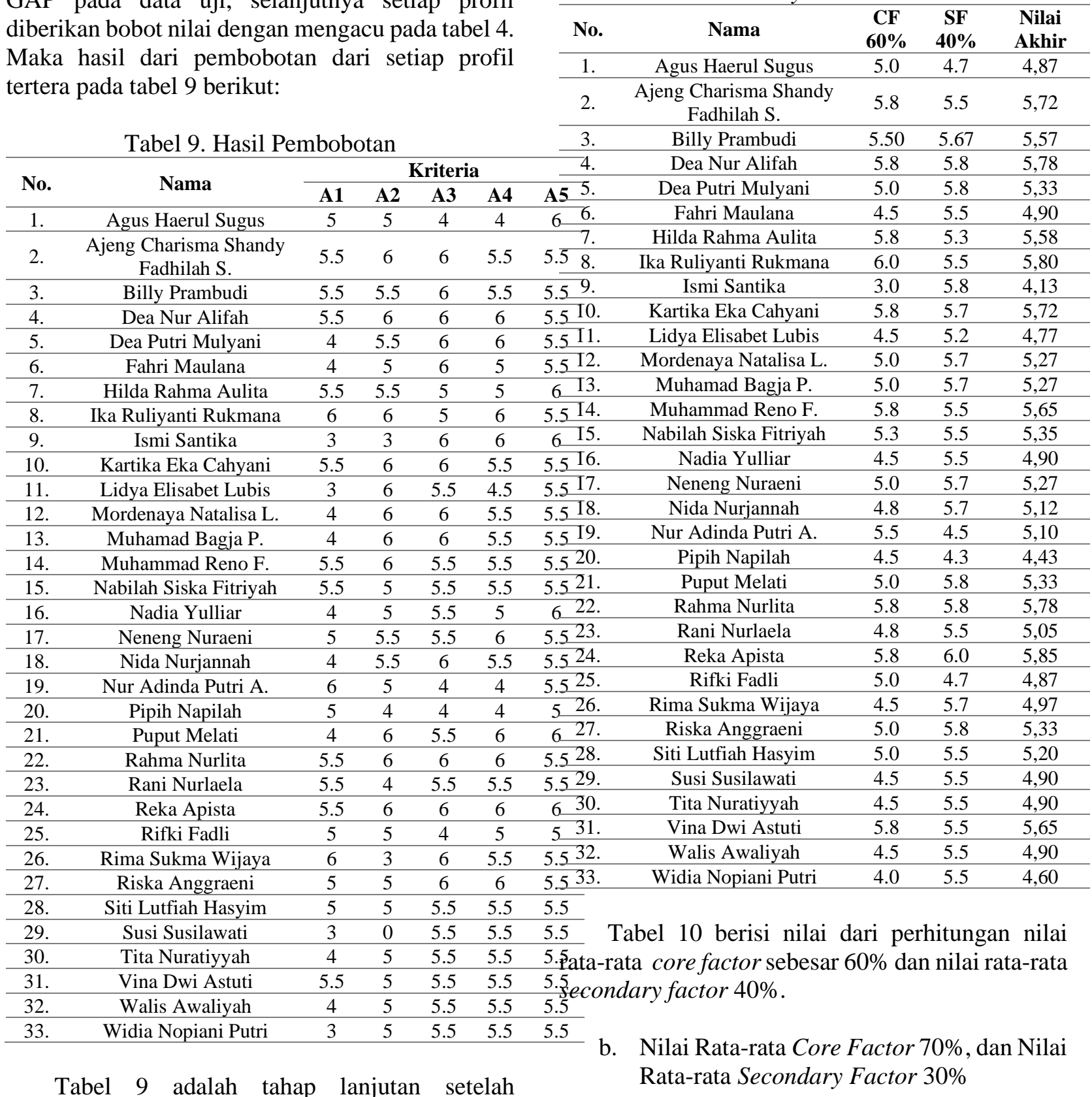

Tabel 9 adalah tahap lanjutan setelah b. Nilai Rata-rata Core Factor $70 \%$, dan Nilai Rata-rata Secondary Factor 30\%

Tabel 5. Rata-rata Core Factor 60\%, dan Rata-rata Secondary Factor $40 \%$

pemetaan nilai dari masing-masing profil. Pemetaan nilai yang didapatkan, dilakukan penentuan bobot yang mengacu pada tabel 4 bobot nilai GAP. 
Tabel 6. Rata-rata Core Factor 70\%, Rata-rata Secondary Factor $30 \%$

\begin{tabular}{|c|c|c|c|c|}
\hline No. & Nama & $\begin{array}{c}\text { CF } \\
70 \%\end{array}$ & $\begin{array}{c}\text { SF } \\
30 \%\end{array}$ & $\begin{array}{l}\text { Nilai } \\
\text { Akhir }\end{array}$ \\
\hline 1. & Agus Haerul Sugus & 5.0 & 4.7 & 4,90 \\
\hline 2. & $\begin{array}{c}\text { Ajeng Charisma Shandy } \\
\text { Fadhilah S. }\end{array}$ & 5.8 & 5.5 & 5,73 \\
\hline 3. & Billy Prambudi & 5.50 & 5.67 & 5,55 \\
\hline 4. & Dea Nur Alifah & 5.8 & 5.8 & 5,78 \\
\hline 5. & Dea Putri Mulyani & 5.0 & 5.8 & 5,25 \\
\hline 6. & Fahri Maulana & 4.5 & 5.5 & 4,80 \\
\hline 7. & Hilda Rahma Aulita & 5.8 & 5.3 & 5,63 \\
\hline 8. & Ika Ruliyanti Rukmana & 6.0 & 5.5 & 5,85 \\
\hline 9. & Ismi Santika & 3.0 & 5.8 & 3,85 \\
\hline 10. & Kartika Eka Cahyani & 5.8 & 5.7 & 5,73 \\
\hline 11. & Lidya Elisabet Lubis & 4.5 & 5.2 & 4,70 \\
\hline 12. & Mordenaya Natalisa L. & 5.0 & 5.7 & 5,20 \\
\hline 13. & Muhamad Bagja P. & 5.0 & 5.7 & 5,20 \\
\hline 14. & Muhammad Reno F. & 5.8 & 5.5 & 5,68 \\
\hline 15. & Nabilah Siska Fitriyah & 5.3 & 5.5 & 5,33 \\
\hline 16. & Nadia Yulliar & 4.5 & 5.5 & 4,80 \\
\hline 17. & Neneng Nuraeni & 5.0 & 5.7 & 5,20 \\
\hline 18. & Nida Nurjannah & 4.8 & 5.7 & 5,03 \\
\hline 19. & Nur Adinda Putri A. & 5.5 & 4.5 & 5,20 \\
\hline 20. & Pipih Napilah & 4.5 & 4.3 & 4,45 \\
\hline 21. & Puput Melati & 5.0 & 5.8 & 5,25 \\
\hline 22. & Rahma Nurlita & 5.8 & 5.8 & 5,78 \\
\hline 23. & Rani Nurlaela & 4.8 & 5.5 & 4,98 \\
\hline 24. & Reka Apista & 5.8 & 6.0 & 5,83 \\
\hline 25. & Rifki Fadli & 5.0 & 4.7 & 4,90 \\
\hline 26. & Rima Sukma Wijaya & 4.5 & 5.7 & 4,85 \\
\hline 27. & Riska Anggraeni & 5.0 & 5.8 & 5,25 \\
\hline 28. & Siti Lutfiah Hasyim & 5.0 & 5.5 & 5,15 \\
\hline 29. & Susi Susilawati & 4.5 & 5.5 & 4,80 \\
\hline 30. & Tita Nuratiyyah & 4.5 & 5.5 & 4,80 \\
\hline 31. & Vina Dwi Astuti & 5.8 & 5.5 & 5,68 \\
\hline 32. & Walis Awaliyah & 4.5 & 5.5 & 4,80 \\
\hline 33. & Widia Nopiani Putri & 4.0 & 5.5 & 4,45 \\
\hline
\end{tabular}

Tabel 11 berisi nilai perhitungan core factor sebesar $70 \%$ dan secondary factor $30 \%$. Pada tabel ini terjadi penurunan nilai dari setiap profil yang disebabkan oleh nilai kriteria core factor dan secondary factor yang dimiliki. Penurunan nilai terjadi ketika nilai kriteria core factor lebih ke kecil daripada nilai kriteria secondary factor.

c. Nilai rata-rata Core Factor $80 \%$, dan Nilai rata-rata Secondary Factor 20\%

Tabel 7. Rata-rata Core Factor $80 \%$, Rata-rata Secondary Factor 20\%

\begin{tabular}{ccccc}
\hline No. & Nama & $\begin{array}{c}\text { CF } \\
\mathbf{7 0 \%}\end{array}$ & $\begin{array}{c}\text { SF } \\
\mathbf{3 0 \%}\end{array}$ & $\begin{array}{c}\text { Nilai } \\
\text { Akhir }\end{array}$ \\
\hline 1. & Agus Haerul Sugus & 5.0 & 4.7 & 4,93 \\
\hline 2. & $\begin{array}{c}\text { Ajeng Charisma Shandy } \\
\text { Fadhilah S. }\end{array}$ & 5.8 & 5.5 & 5,74 \\
\hline 3. & Billy Prambudi & 5.50 & 5.67 & 5,53 \\
\hline 4. & Dea Nur Alifah & 5.8 & 5.8 & 5,77 \\
\hline 5. & Dea Putri Mulyani & 5.0 & 5.8 & 5,17 \\
\hline
\end{tabular}

\begin{tabular}{ccccc}
\hline 6. & Fahri Maulana & 4.5 & 5.5 & 4,70 \\
\hline 7. & Hilda Rahma Aulita & 5.8 & 5.3 & 5,67 \\
\hline 8. & Ika Ruliyanti Rukmana & 6.0 & 5.5 & 5,90 \\
\hline 9. & Ismi Santika & 3.0 & 5.8 & 3,57 \\
\hline 10. & Kartika Eka Cahyani & 5.8 & 5.7 & 5,73 \\
\hline 11. & Lidya Elisabet Lubis & 4.5 & 5.2 & 4,63 \\
\hline 12. & Mordenaya Natalisa L. & 5.0 & 5.7 & 5,13 \\
\hline 13. & Muhamad Bagja P. & 5.0 & 5.7 & 5,13 \\
\hline 14. & Muhammad Reno F. & 5.8 & 5.5 & 5,70 \\
\hline 15. & Nabilah Siska Fitriyah & 5.3 & 5.5 & 5,30 \\
\hline 16. & Nadia Yulliar & 4.5 & 5.5 & 4,70 \\
\hline 17. & Neneng Nuraeni & 5.0 & 5.7 & 5,13 \\
\hline 18. & Nida Nurjannah & 4.8 & 5.7 & 4,93 \\
\hline 19. & Nur Adinda Putri A. & 5.5 & 4.5 & 5,30 \\
\hline 20. & Pipih Napilah & 4.5 & 4.3 & 4,47 \\
\hline 21. & Puput Melati & 5.0 & 5.8 & 5,17 \\
\hline 22. & Rahma Nurlita & 5.8 & 5.8 & 5,77 \\
\hline 23. & Rani Nurlaela & 4.8 & 5.5 & 4,90 \\
\hline 24. & Reka Apista & 5.8 & 6.0 & 5,80 \\
\hline 25. & Rifki Fadli & 5.0 & 4.7 & 4,93 \\
\hline 26. & Rima Sukma Wijaya & 4.5 & 5.7 & 4,73 \\
\hline 27. & Riska Anggraeni & 5.0 & 5.8 & 5,17 \\
\hline 28. & Siti Lutfiah Hasyim & 5.0 & 5.5 & 5,10 \\
\hline 29. & Susi Susilawati & 4.5 & 5.5 & 4,70 \\
\hline 30. & Tita Nuratiyyah & 4.5 & 5.5 & 4,70 \\
\hline 31. & Vina Dwi Astuti & 5.8 & 5.5 & 5,70 \\
\hline 32. & Walis Awaliyah & 4.5 & 5.5 & 4,70 \\
\hline 33. & Widia Nopiani Putri & 4.0 & 5.5 & 4,30 \\
\hline & & & &
\end{tabular}

Tabel 12 dilakukan perhitungan dengan nilai persentase core factor $80 \%$ dan secondary factor $20 \%$. Terjadi perubahan nilai dari setiap profil menjadi lebih besar dari perhitungan sebelumnya jika nilai kriteria core factor lebih besar daripada nilai kriteria secondary factor.

3. Pemeringkatan

a. Core Factor $60 \%$, Secondary Factor $40 \%$

Tabel 8. Pemeringkatan CF 60\% SF 40\%

\begin{tabular}{ccc}
\hline No. & Nama & Nilai Akhir \\
\hline 1. & Reka Apista & 5,85 \\
\hline 2. & Ika Ruliyanti Rukmana & 5,80 \\
\hline 3. & Dea Nur Alifah & 5,78 \\
\hline 4. & Rahma Nurlita & 5,78 \\
\hline 5. & Kartika Eka Cahyani & 5,72 \\
\hline 6. & Ajeng Charisma Shandy Fadhilah S. & 5,72 \\
\hline 7. & Muhammad Reno Firdaus & 5,65 \\
\hline 8. & Vina Dwi Astuti & 5,65 \\
\hline 9. & Hilda Rahma Aulita & 5,58 \\
\hline 10. & Billy Prambudi & 5,57 \\
\hline 11. & Nabilah Siska Fitriyah & 5,35 \\
\hline 12. & Dea Putri Mulyani & 5,33 \\
\hline 13. & Puput Melati & 5,33 \\
\hline 14. & Riska Anggraeni & 5,33 \\
\hline 15. & Mordenaya Natalisa Lubis & 5,27 \\
\hline 16. & Muhamad Bagja Pamungkas & 5,27 \\
\hline 17. & Neneng Nuraeni & 5,27 \\
\hline 18. & Siti Lutfiah Hasyim & 5,20 \\
\hline 19. & Nida Nurjannah & 5,12 \\
\hline 20. & Nur Adinda Putri Amanda & 5,10 \\
\hline
\end{tabular}




\begin{tabular}{ccc}
\hline 21. & Rani Nurlaela & 5,05 \\
\hline 22. & Rima Sukma Wijaya & 4,97 \\
\hline 23. & Fahri Maulana & 4,90 \\
\hline 24. & Nadia Yulliar & 4,90 \\
\hline 25. & Tita Nuratiyyah & 4,90 \\
\hline 26. & Walis Awaliyah & 4,90 \\
\hline 27. & Agus Haerul Sugus & 4,87 \\
\hline 28. & Rifki Fadli & 4,87 \\
\hline 29. & Lidya Elisabet Lubis & 4,77 \\
\hline 30. & Susi Susilawati & 4,90 \\
\hline 31. & Widia Nopiani Putri & 4,60 \\
\hline 32. & Pipih Napilah & 4,43 \\
\hline 33. & Ismi Santika & 4,13 \\
\hline
\end{tabular}

Tabel 13 berisi pemeringkatan nilai berdasarkan nilai tertinggi pada perhitungan core factor $60 \%$ dan secondary factor $40 \%$. Terlihat bahwa terdapat beberapa profil yang memiliki nilai akhir sama di urutan tertentu.

\section{b. Core Factor $70 \%$, Secondary Factor $30 \%$}

Tabel 9. Pemeringkatan CF 70\% SF 30\%

\begin{tabular}{ccc}
\hline No. & Nama & Nilai Akhir \\
\hline 1. & Ika Ruliyanti Rukmana & 5,85 \\
\hline 2. & Reka Apista & 5,83 \\
\hline 3. & Dea Nur Alifah & 5,78 \\
\hline 4. & Rahma Nurlita & 5,78 \\
\hline 5. & Ajeng Charisma Shandy Fadhilah S. & 5,73 \\
\hline 6. & Kartika Eka Cahyani & 5,73 \\
\hline 7. & Muhammad Reno Firdaus & 5,68 \\
\hline 8. & Vina Dwi Astuti & 5,68 \\
\hline 9. & Hilda Rahma Aulita & 5,63 \\
\hline 10. & Billy Prambudi & 5,55 \\
\hline 11. & Nabilah Siska Fitriyah & 5,33 \\
\hline 12. & Dea Putri Mulyani & 5,25 \\
\hline 13. & Puput Melati & 5,25 \\
\hline 14. & Riska Anggraeni & 5,25 \\
\hline 15. & Mordenaya Natalisa Lubis & 5,20 \\
\hline 16. & Muhamad Bagja Pamungkas & 5,20 \\
\hline 17. & Neneng Nuraeni & 5,20 \\
\hline 18. & Nur Adinda Putri Amanda & 5,20 \\
\hline 19. & Siti Lutfiah Hasyim & 5,15 \\
\hline 20. & Nida Nurjannah & 5,03 \\
\hline 21. & Rani Nurlaela & 4,98 \\
\hline 22. & Agus Haerul Sugus & 4,90 \\
\hline 23. & Rifki Fadli & 4,90 \\
\hline 24. & Rima Sukma Wijaya & 4,85 \\
\hline 25. & Fahri Maulana & 4,80 \\
\hline 26. & Nadia Yulliar & 4,80 \\
\hline 27. & Susi Susilawati & 4,80 \\
\hline 28. & Tita Nuratiyyah & 4,80 \\
\hline 29. & Walis Awaliyah & 4,80 \\
\hline 30. & Lidya Elisabet Lubis & 4,70 \\
\hline 31. & Pipih Napilah & 4,45 \\
\hline 32. & Widia Nopiani Putri & 4,45 \\
\hline 33. & Ismi Santika & 3,85 \\
\hline
\end{tabular}

Tabel 14 berisi pengurutan nilai dengan perhitungan core factor sebesar $70 \%$ dan secondary factor $30 \%$. Terjadi pertukaran posisi pada urutan 1 dan 2. Jika pada pemeringkatan dengan nilai core factor $60 \%$ dan secondary factor $40 \%$, yang berada diurutan pertama yaitu Reka Apista dengan nilai 5.85 dilanjutkan oleh Ika Ruliyanti Rukmana dengan nilai 5.80. pada tabel 15 , urutan pertama didapatkan oleh Ika dengan nilai 5.85 dan dilanjutkan oleh Reka dengan nilai 5.83 .

\section{c. Core Factor $80 \%$, Secondary Factor $20 \%$}

Tabel 10. Pemeringkatan CF $80 \%$ SF $20 \%$

\begin{tabular}{|c|c|c|}
\hline No. & Nama & Nilai Akhir \\
\hline 1. & Ika Ruliyanti Rukmana & 5,90 \\
\hline 2. & Reka Apista & 5,80 \\
\hline 3. & Dea Nur Alifah & 5,77 \\
\hline 4. & Rahma Nurlita & 5,77 \\
\hline 5. & Ajeng Charisma Shandy Fadhilah S. & 5,73 \\
\hline 6. & Kartika Eka Cahyani & 5,73 \\
\hline 7. & Muhammad Reno Firdaus & 5,70 \\
\hline 8. & Vina Dwi Astuti & 5,70 \\
\hline 9. & Hilda Rahma Aulita & 5,67 \\
\hline 10. & Billy Prambudi & 5,53 \\
\hline 11. & Nabilah Siska Fitriyah & 5,30 \\
\hline 12. & Nur Adinda Putri Amanda & 5,30 \\
\hline 13. & Dea Putri Mulyani & 5,17 \\
\hline 14. & Puput Melati & 5,17 \\
\hline 15. & Riska Anggraeni & 5,17 \\
\hline 16. & Mordenaya Natalisa Lubis & 5,13 \\
\hline 17. & Muhamad Bagja Pamungkas & 5,13 \\
\hline 18. & Neneng Nuraeni & 5,13 \\
\hline 19. & Siti Lutfiah Hasyim & 5,10 \\
\hline 20. & Agus Haerul Sugus & 4,93 \\
\hline 21. & Nida Nurjannah & 4,93 \\
\hline 22. & Rifki Fadli & 4,93 \\
\hline 23. & Rani Nurlaela & 4,90 \\
\hline 24. & Rima Sukma Wijaya & 4,73 \\
\hline 25. & Fahri Maulana & 4,70 \\
\hline 26. & Nadia Yulliar & 4,70 \\
\hline 27. & Susi Susilawati & 4,70 \\
\hline 28. & Tita Nuratiyyah & 4,70 \\
\hline 29. & Walis Awaliyah & 4,70 \\
\hline 30. & Lidya Elisabet Lubis & 4,63 \\
\hline 31. & Pipih Napilah & 4,47 \\
\hline 32. & Widia Nopiani Putri & 4,30 \\
\hline 33. & Ismi Santika & 3,57 \\
\hline
\end{tabular}

Tabel 15 merupakan proses pemeringkatan dari perhitungan core factor $80 \%$ dan secondary factor 20\%. Yang berada di urutan 1 dan 2 tidak berubah. Namun nilai dari keduanya mengalami perubahan.

\subsection{Evaluasi}

Berdasarkan tahapan dari penelitian yang telah dilakukan, didapatkan kesimpulan bahwa aplikasi yang dibangun dapat digunakan untuk 
proses ujian seleksi mahasiswa baru di Sekolah Tinggi Ilmu Kesehatan Kuningan.

Pengujian yang dilakukan menghasilkan tingkat akurasi yang berbeda yang disebabkan oleh konsep dari perhitungan algoritma profile matching, di mana terdapat skala nilai yang menjadi peluang terbesar terjadinya nilai akhir yang sama di beberapa profil.

Penerapan algoritma profile matching pada sebuah aplikasi Computer Based Test (CBT) ini belum menghasilkan nilai yang optimal, sehingga perlu dilakukan penelitian lebih lanjut dengan penerapan algoritma pemeringkatan yang lain.

\section{Kesimpulan}

Berdasarkan penelitian yang telah dilakukan, diperoleh kesimpulan sebagai berikut:

a. Aplikasi Computer Based Test (CBT) dengan penerapan algoritma Profile Matching yang dibangun dapat digunakan untuk mempermudah dan mempercepat dalam pelaksanaan ujian seleksi mahasiswa baru dan pengolahan data nilai dari hasil ujian tersebut.

b. Pengujian dilakukan dengan membandingkan hasil perhitungan pada sistem dan perhitungan excel di mana terdapat 3 nilai Core Factor dan Secondary Factor yang berbeda. Terdapat ketidaksesuaian pada hasil pengujian ketika ada beberapa profil yang memiliki nilai akhir yang sama. Salah satunya, Dea Nur Alifah dan Rahma Nurlita dengan nilai CF 60\%, SF $40 \%$ dan $\mathrm{CF} 70 \%$, SF $30 \%$ memiliki nilai akhir sebesar 5.78, berada pada urutan 3 dan 4 . Selanjutnya pada nilai CF $80 \%$ dan SF $20 \%$ keduanya mengalami penurunan nilai, menjadi 5.77 serta masih berada di urutan 3 dan 4. Penerapan algoritma Profile Matching dengan output berupa peringkat atau pengurutan nilai dalam aplikasi Computer Based Test (CBT) ini belum optimal, sehingga perlu dilakukan penelitian dengan penerapan algoritma yang lain.

\section{Referensi}

Ariyanti, H. (2017). Penerapan Metode Profile Matching Pada Seleksi Atlet Untuk Masuk Dalam Kejuaraan Pencak Silat (Studi Kasus pada UKM Pencak Silat PSHT Universitas Nusantara PGRI Kediri). Artikel Skripsi Universitas Nusantara PGRI Kediri, 1-7.

Astari, S. R., Umar, R., \& Sunardi. (2019, April). Penerapan Profile Matching Untuk Seleksi Asisten Laboratorium. TELEMATIKA, Vol. 16 No. 1, 1-10.
Fasya, F., Arifin, M. Z., Muttaqin, Z., Sukur, R. S., \& Kusrini. (2018, Maret). Penerapan Metode Profile Matching Pada Sistem Pendukung Keputusan Untuk Memilih Calon Penerima Beasiswa Bidikmisi. Cahaya Tech, Vol. 7 No. 01, 50-61.

Gusriva, R. (2019, Desember). Profile Matching Untuk Pemilihan Kepala Bidang Pada Dinas Kominfo Provinsi Sumatera Barat. JURNAL J - CLICK, Vol. 6 No. 2, 170-175.

Hariyanto, A. (2017). Membuat Aplikasi Computer Based Test dengan PHP, MySQLi dan Bootsrap. Yogyakarta: Lokomedia.

Hernawati; Husnayain, Shefiana;. (2018). Perancangan Sistem Pendukung Keputusan Penilaian Kinerja Pegawai Menggunakan Metode Algoritma Profile Matching Studi Kasus: Universitas Nurtanio. FIKI |Jurnal Teknologi Informasi dan Komunikasi |ISSN : 2087-2372, Volume IX, No. 1, 20-28.

Imtihan, K., Hadawiyah, R., \& Asyari, H. (2017). Sistem Informasi Penggajian Guru Honorer Menggunakan Konsep Agile Software Development dengan Metodologi Extreme Programming (XP) pada SMK Bangun Bangsa. Indonesian Journal on Networking and Security, Volume 7 No. 2, 32-37.

Mahdia, I. S., Solikhun, \& M. Fauzan. (2019, Oktober). Penerapan Metode Profile Matching Dalam Merekomendasikan Bibit Kelapa Sawit. KOMIK (Konferensi Nasional Teknologi Informasi dan Komputer), Volume 3, Nomor 1, 652-658. doi:10.30865/komik.v3i1.1674

Mupidah. (2019). Implementasi Metode Profile Matching Dan Analytical Hierarchi Process (AHP) Pada Perekrutan Tenaga Kurir. Jurnal Pelita Informatika, Volume 18, Nomor 4, Oktober 2019, ISSN 2301-9425 (Media Cetak), 608-615.

Nas, C., Defit, S., \& Santoni, J. (2018, Desember). Evaluasi Mutasi Jabatan Anggota Kepolisian Menggunakan Metode Profile Matching dan Multi Attribute Utility Theory. Jurnal Sains, Teknologi dan Industri, Vol. 16, No. 1, 30-36.

Nofriansyah, D. (2017). Konsep Data Mining VS Sistem Pendukung Keputusan. Yogyakarta: Deepublish.

Nofriansyah, D., \& Defit, S. (2017). Multi Criteria Decision Making pada Sistem Pendukung Keputusan. Yogyakarta: Deepublish.

Prabowo, M., \& Suprapto, A. (2019). Implementasi Metode Profile Matching Dalam Aplikasi Penerimaan Siswa Baru pada SMK Ma'arif NU 2 Boyolali. JUSIFO Jurnal Sistem Informasi, 5 Nomor 2, 71-80.

Pratistha, Indra; Mahadewa, Agung; Sugiartawan, Putu;. (2018). Sistem Pendukung Keputusan Kelompok Pemilihan E-Commerce Menggunakan Metode Profile Matching dan 
BORDA. Jurnal Sistem Informasi dan Komputer Terapan Indonesia (JSIKTI), Vol.1, No.1, 13-24.

Pressman, Ph.D., R. (2012). Rekayasa Perangkat Lunak Pendekatan Praktisi Edisi 7 Buku 1. Yogyakarta: Andi Publisher.

Putra, R. R., \& Sugihartono, T. (2019). Penerapan Algoritma Fisher-Yates Shuffle Pada Computer Based Test Ujian Sekolah Di SMKN 1 Payung. Jurnal MATRIK, Hal 276-283.

Putratama, S. V. (2016). Pemrograman Web dengan Menggunakan PHP dan Framework Codeigniter. Yogyakarta: Deepublish.
Riswandi, I. (2017, September). Sistem Penunjang Keputusan Penerimaan Karyawan Menggunakan Metode Profile Matching dan Analytical Hierarchy Process Pada PT. Sunny Collection. Perspektif, Vol. XV, No. 2, 136-146.

Rosa A. S, \& Shalahuddin, M. (2016). Rekayasa Perangkat Lunak Terstruktur dan Berorientasi Objek. Bandung: Informatika.

Sunarti; Sundari, Jenie. (2018). Perbandingan Metode SAW dan Profile Matching Pada Pemilihan Rumah Tinggal Studi Kasus: Perumahan Depok. INTENSIF, Vol.2 No.2 August 2018, ISSN: 2580-409X (Print) /2549-6824 (Online), 115. 